\title{
Electrophysical agents in clinical practice of orthopedic and sports physical therapists in Brazil
}

\author{
Agentes eletrofísicos na prática clinica de fisioterapeutas ortopédicos e esportivos no Brasil \\ Agentes electrofísicos en la práctica clinica de fisioterapeutas ortopédicos y deportivos en Brasil \\ Francine Pereira da Silva', Lucas Severo-Silveira², Rodrigo Della Méa Plentz³ , João Luiz Quagliotti Durigan, \\ Bruno Manfredini Baroni ${ }^{5}$
}

\begin{abstract}
Studies have described the use of electrophysical agents (EPA) by physical therapists worldwide. However, the use of EPA by Brazilian physical therapists remains undetermined. This study aims to describe the availability, use, and perception about EPA by orthopedic and sports physical therapists in Brazil. Professionals of the area were invited to answer an online questionnaire. Demographic data and information regarding the availability, use and perception about EPA in their current clinical practice were asked. Out of 376 physical therapists included in this study, 89\% declared to use EPA in clinical practice. Sensory electrotherapy with pulsed current (TENS), therapeutic ultrasound, excitomotor electrotherapy with pulsed current (FES/NMES), and cryotherapy are available for more than 3/4 of interviewees. Scientific articles and clinical experience, respectively, are the most influential factors for the choice of EPA. Ultrasound is the most frequently used EPA, followed by TENS, cryotherapy, photobiomodulation, hot packs, and FES/NMES. The top-five most useful EPA in clinical practice chosen by physical therapists are: (1) ultrasound; (2) photobiomodulation; (3) TENS; (4) cryotherapy; and (5) FES/NMES. In conclusion, EPA are widely used by orthopedic and sports physical therapists in Brazil. Therapeutic ultrasound, TENS, FES/NMES, photobiomodulation, cryotherapy, and hot packs are the most used EPA in clinical practice of these physiotherapists.
\end{abstract}

Keywords | Physical Therapy; Electric Stimulation Therapy; Ultrasonic Therapy; Cryotherapy.

RESUMO I Estudos têm descrito a utilização de agentes eletrofísicos (AE) por fisioterapeutas ao redor do mundo. No entanto, o uso de AE por fisioterapeutas brasileiros permanece inexplorado. O objetivo deste estudo é descrever o acesso, a utilização e a percepção sobre os AE de fisioterapeutas ortopédicos e esportivos no Brasil. Os profissionais foram convidados a responder um questionário on-line. Foram solicitados dados demográficos e informações sobre o acesso, utilização e percepção dos profissionais sobre os AE na prática clínica. Dentre os 376 fisioterapeutas incluídos, 89\% declararam ser usuários de AE na prática clínica. Eletroterapia sensorial com corrente pulsada (TENS), ultrassom terapêutico, eletroterapia excitomotora com corrente pulsada (FES/ NMES) e crioterapia são acessíveis para mais de 3/4 dos participantes. Artigos científicos e experiência clínica são os fatores de maior influência na escolha por AE. O ultrassom é o AE mais frequentemente utilizado, seguido por Tens, crioterapia, fotobiomodulação, bolsas quentes e FES/NMES. Os cinco AE elencados pelos fisioterapeutas como mais úteis na prática clínica são: (1) ultrassom; (2) fotobiomodulação; (3) TENS; (4) crioterapia; e (5) FES/ NMES. Em conclusão, os AE são largamente usados pelos

Study conducted at Federal University of Health Sciences of Porto Alegre (UFCSPA), Porto Alegre (RS), Brazil.

'Universidade Federal de Ciências da Saúde de Porto Alegre (UFCSPA) - Porto Alegre (RS), Brazil. E-mail: franh.pereira@hotmail.com. Orcid: 0000-0002-1311-1864

2Universidade Federal de Ciências da Saúde de Porto Alegre (UFCSPA) - Porto Alegre (RS), Brazil. E-mail: severo.fisio@gmail.com. Orcid: 0000-0002-5517-0053

3 Universidade Federal de Ciências da Saúde de Porto Alegre (UFCSPA) - Porto Alegre (RS), Brazil. E-mail: roplentz@yahoo.com.br. Orcid: 0000-0002-2662-8192

4Universidade de Brasília (UnB) - Brasília (DF), Brazil. E-mail: joaodurigan@gmail.com. Orcid: 0000-0002-7511-5289

${ }_{5}$ Universidade Federal de Ciências da Saúde de Porto Alegre (UFCSPA) - Porto Alegre (RS), Brazil. E-mail: bmbaroni@yahoo.com.br. Orcid: 0000-0002-8669-5565 
fisioterapeutas ortopédicos e esportivos no Brasil. Ultrassom terapêutico, TENS, FES/NMES, fotobiomodulação, crioterapia e bolsas quentes são os AE mais usados na prática clínica desses fisioterapeutas.

Descritores | Fisioterapia; Terapia por Estimulação Elétrica; Terapia por Ultrassom; Crioterapia.

RESUMEN I Los estudios ya han descrito el uso de agentes electrofísicos (AE) por fisioterapeutas en todo el mundo. Todavía no se ha explorado el uso de los AE por fisioterapeutas brasileños. El presente estudio tuvo como objetivo describir el acceso, el uso y la percepción sobre los AE por fisioterapeutas ortopédicos y deportivos en Brasil. Se invitó a los profesionales para responder a un cuestionario en línea. Se solicitaron los datos demográficos e informaciones sobre el acceso, el uso y la percepción de profesionales sobre los AE en la práctica clínica. Entre los 376 fisioterapeutas incluidos, el 89\% declararon utilizar los AE en la práctica clínica. La electroterapia sensorial con corriente pulsada (TENS), el ultrasonido terapéutico, la electroterapia excitomotora con corriente pulsada (FES/NMES) y la crioterapia son accesibles para más de 3/4 de los participantes. Los artículos científicos y la experiencia clínica son los factores que más influyeron en la elección de los AE. El ultrasonido es el AE más utilizado, seguido de Tens, crioterapia, fotobiomodulación, bolsas calientes y FES/NMES. Los cinco AE más útiles en la práctica clínica enumerados por los fisioterapeutas fueron: (1) ultrasonido; (2) fotobiomodulación; (3) TENS; (4) crioterapia; y (5) FES/NMES. Los AE son ampliamente utilizados por los profesionales de la ortopedia y el deporte en Brasil. El ultrasonido terapéutico, TENS, FES/NMES, fotobiomodulación, crioterapia y bolsas calientes son los AE más utilizados en la práctica clínica por estos fisioterapeutas. Palabras clave | Terapia por Estimulación Eléctrica; Electroterapia; Terapia por Ultrasonido; Crioterapia.

\section{INTRODUCTION}

According to the World Confederation for Physical Therapy (WCPT), "electrophysical agents" (EPA) is the contemporary expression to describe the use of electrophysical and biophysical energies to evaluate, to treat and to prevent impairments, activity limitations, and participation restrictions ${ }^{1}$. Physical therapists have used electrical, electromagnetic, mechanical, thermal, and light energy sources to promote biophysical effects on cells, tissues, and organs in order to generate physiological and therapeutic effects for optimization of health for several decades (or centuries, in some cases) ${ }^{2-4}$. However, EPA remain an adjunct treatment within physical therapists' multimodal approach ${ }^{5,6}$. In face of scientific and technological advances, novel devices have emerged and new applications for traditional techniques have been tested ${ }^{6}$. Therefore, teaching EPA in physical therapy courses must evolve constantly ${ }^{7,8}$ and should be guided by scientific evidence, availability of equipment in the market, and physical therapists' preferences.

Since the 1990s, studies have been conducted to describe the availability and use of EPA by physical therapists in different countries, such as Australia ${ }^{9-11}$, the United States of America ${ }^{12,13}$, Canada ${ }^{14}$, England ${ }^{15}$, Ireland ${ }^{16}$, Israel ${ }^{17}$, and Japan ${ }^{18}$. After extensive review of studies published between 1990 and 2010, Shah \& Farrow $^{19}$ concluded that the use of EPA underwent significant changes throughout that period. According to studies published in the last decade ${ }^{11,13,17,18}$, therapeutic ultrasound, sensory electrotherapy with pulsed current (popularly known as TENS - transcutaneous electrical nerve stimulation), hot packs and cryotherapy are the EPA most commonly used by physical therapists. The therapeutic arsenal of physical therapists also includes: excitomotor pulsed currents, commonly known as FES (functional electrical stimulation) or NMES (neuromuscular electrical stimulation); alternating currents (e.g., interferential current and Russian current); direct current (galvanic current); short-wave diathermy; microwave diathermy; photobiomodulation/ phototherapy with light amplification by stimulated emission of radiation (LASER) and/or light emitting diode (LED); and biofeedback, among others ${ }^{11,13,17,18}$.

Information regarding the availability and use of EPA by physical therapists have been provided by studies conducted in Oceania ${ }^{9-11}$, North America ${ }^{12-14}$, Europe ${ }^{15,16}$, and Asia ${ }^{17,18}$. Since physical therapists working in different countries have specific trends in the use of $\mathrm{EPA}^{19}$, previous findings do not represent the Brazilian scenario, a country with around 240,000 of these professionals ${ }^{20}$. Moreover, physical therapy comprises a range of clinical specialties meeting the needs of different groups of patients, and professionals present a selectivity of EPA according to their specialty (e.g., musculoskeletal, neurological, or cardiorespiratory rehabilitation). Many Brazilian physical therapists are involved with rehabilitation of 
musculoskeletal disorders, but their usage profile of EPA remains unknown. Therefore, this study aims to describe the availability, use and perception about EPA by orthopedic and sports physical therapists in Brazil.

\section{METHODOLOGY}

\section{Study design}

In this cross-sectional study, participants answered an online questionnaire on the availability, use and perception about EPA. All participants agreed to participate, signing an online consent term.

\section{Participants}

Announcements were posted on social networks linked to physical therapy in Brazil, inviting physical therapists to access the online survey-website and to respond the questionnaire. Professionals working anywhere in Brazil and without specialty-related restriction were accepted in this phase. Then, only professionals who declared to work in orthopedic and/ or sports physical therapy were considered for analysis, regardless of the facilities where they provided the service (e.g., office, clinic, ambulatory, hospital, sports club, etc.).

\section{Survey}

A draft questionnaire was created using models provided by studies on the use of EPA published in the last decade ${ }^{11,13,17,18}$. Three physical therapists with $\mathrm{PhD}$ degree, researchers in the field of EPA, and involved with teaching EPA in universities throughout Brazil, reviewed the draft questionnaire for content validity and also to address potential differences in nomenclature for Portuguese language. The online version of the final questionnaire was available in the Google Forms website (https://www.google.com/forms/about/).

The online questionnaire had two phases. The first phase comprised demographic data: gender, age, location (state), type of university where they attended the physical therapy graduation (public or private), graduation year, highest academic degree, daily workload (in hours), and occupation area (e.g., orthopedic physical therapy, sports physical therapy). The last question in that phase was: "Do you use EPA in your clinical practice?."When participant answered "NO," the survey was finished; and they advanced to the next phase when the answer was "YES." In the second phase, the following multiple choice questions were asked for interviewees:

1) "What EPA are available at your workplace?" Participants were free to mark as many options as they preferred, including: therapeutic ultrasound, direct current (galvanic), sensory electrotherapy with pulsed current (TENS), excitomotor electrotherapy with pulsed current (FES/NMES), interferential current, Russian current, photobiomodulation (LASER/ LED), cryotherapy, hot packs, infrared lamp, ultraviolet lamp, microwave diathermy, shortwave diathermy, biofeedback, others (participant was asked to describe).

2) "How do the factors listed below influence the choice of EPA in your clinical practice?" - Participants were asked to mark one of the possible answers (i.e., large influence; medium influence; little influence; or no influence) for each of the following factors: scientific articles; books; websites; undergraduate classes; courses/events; clinical experience; contact with colleagues; patient's preference.

3) "What is the approximate percentage of patients that you use each EPA?" - Participants should mark one of the following answers for each EPA: I use it with all my patients; I use it with more than $75 \%$ of my patients; I use it with about $50-75 \%$ of my patients; I use it with about $25-50 \%$ of my patients; I use it with less than $25 \%$ of my patients; or I do not use it with my patients.

4) "Classify (in order of relevance) the five EPA you consider most useful in clinical practice." Participants were asked to mark their opinion from the first to the fifth most useful EPA.

According to our pilot studies, participants did not need more than 10 minutes to complete the questionnaire. The survey disclosure and the availability of the online questionnaire for those interested in participating were maintained for a period of six months (March to August 2016). At the end of this period, the questionnaire was deactivated, and data were then extracted for analysis.

\section{Statistical analysis}

Absolute and percentage distributions were assessed in each question. For the question that asked participants to list the five most useful EPA in the physical therapists' clinical practice, we adopted the following scale: 5 points 
attributed to EPA listed in the first place; 4 points for the EPA listed in second; 3 points for the third; 2 points for the forth; and 1 point for the fifth. The points obtained by each EPA were summed and the five highest scores were presented in the results.

\section{RESULTS}

In total, 460 physical therapists answered the online questionnaire. A total of 84 participants were excluded from data analysis for not meeting the inclusion criteria regarding the occupation area (i.e., orthopedic and/or sports physical therapy) or due to mistakes identified in filling out the questionnaire. Table 1 presents the characteristics of the 376 physical therapists included in the study.

Table 1. Characteristics of the participants

\begin{tabular}{|c|c|c|}
\hline & $\mathbf{N}$ & $\%$ \\
\hline \multicolumn{3}{|l|}{ Age } \\
\hline 20-29 years & 169 & 44.95 \\
\hline 30-39 years & 147 & 39.10 \\
\hline $40-49$ years & 46 & 12.23 \\
\hline$\geq 50$ years & 14 & 3.72 \\
\hline \multicolumn{3}{|l|}{ Location } \\
\hline Southeast & 164 & 43.62 \\
\hline South & 152 & 40.43 \\
\hline Northeast & 39 & 10.37 \\
\hline Midwest & 13 & 3.46 \\
\hline North & 8 & 2.13 \\
\hline \multicolumn{3}{|l|}{ Experience as physical therapist } \\
\hline Up to 5 years & 137 & 36.44 \\
\hline 6 to 10 years & 108 & 28.72 \\
\hline 11 to 15 years & 62 & 16.49 \\
\hline 15 to 20 years & 39 & 10.37 \\
\hline$>20$ years & 30 & 7.98 \\
\hline \multicolumn{3}{|l|}{ Highest academic degree } \\
\hline Undergraduate course & 106 & 28.19 \\
\hline Specialization / Residence & 199 & 52.93 \\
\hline Master's degree & 52 & 13.83 \\
\hline $\mathrm{PhD}$ & 19 & 5.05 \\
\hline \multicolumn{3}{|l|}{ Daily workload as physical therapist } \\
\hline 1 to 4 hours & 40 & 10.64 \\
\hline 5 to 8 hours & 165 & 43.88 \\
\hline 9 to 12 hours & 171 & 45.48 \\
\hline \multicolumn{3}{|l|}{ Current occupation area } \\
\hline Orthopedic Physical Therapy & 217 & 57.71 \\
\hline Sports Physical Therapy & 21 & 5.59 \\
\hline Orthopedics + Sports Physical Therapy & 138 & 36.70 \\
\hline \multicolumn{3}{|l|}{ Use of EPA in clinical practice } \\
\hline Yes & 336 & 89.36 \\
\hline No & 40 & 10.64 \\
\hline
\end{tabular}

N: number of physical therapists; \%: percent value (total: 376 participants).
A total of 336 physical therapists (89\% of respondents) reported using EPA in their clinical practice. Figures 1 to 4 present the results for these 336 professionals. TENS, ultrasound, FES/NMES, and cryotherapy were available for more than 3/4 of interviewees, followed by LASER/LED and hot packs (Figure 1). Information from scientific articles and clinical experience were considered factors with large influence on the EPA choice by $71 \%$ and $64 \%$ of physical therapists, respectively; whereas website information and patient's preference were the least relevant factors (Figure 2).

Therapeutic ultrasound was used in more than half of their patients by $61 \%$ of the respondents, followed by TENS (54\%), cryotherapy (50\%), LASER/LED (46\%), hot packs (31\%), and FES/NMES (31\%), as illustrated in Figure 3. In the elected top-five EPA for clinical practice (Figure 4), the physical therapists' votes established the following ranking: (1) ultrasound; (2) LASER/LED; (3) TENS; (4) cryotherapy; and (5) FES/NMES.

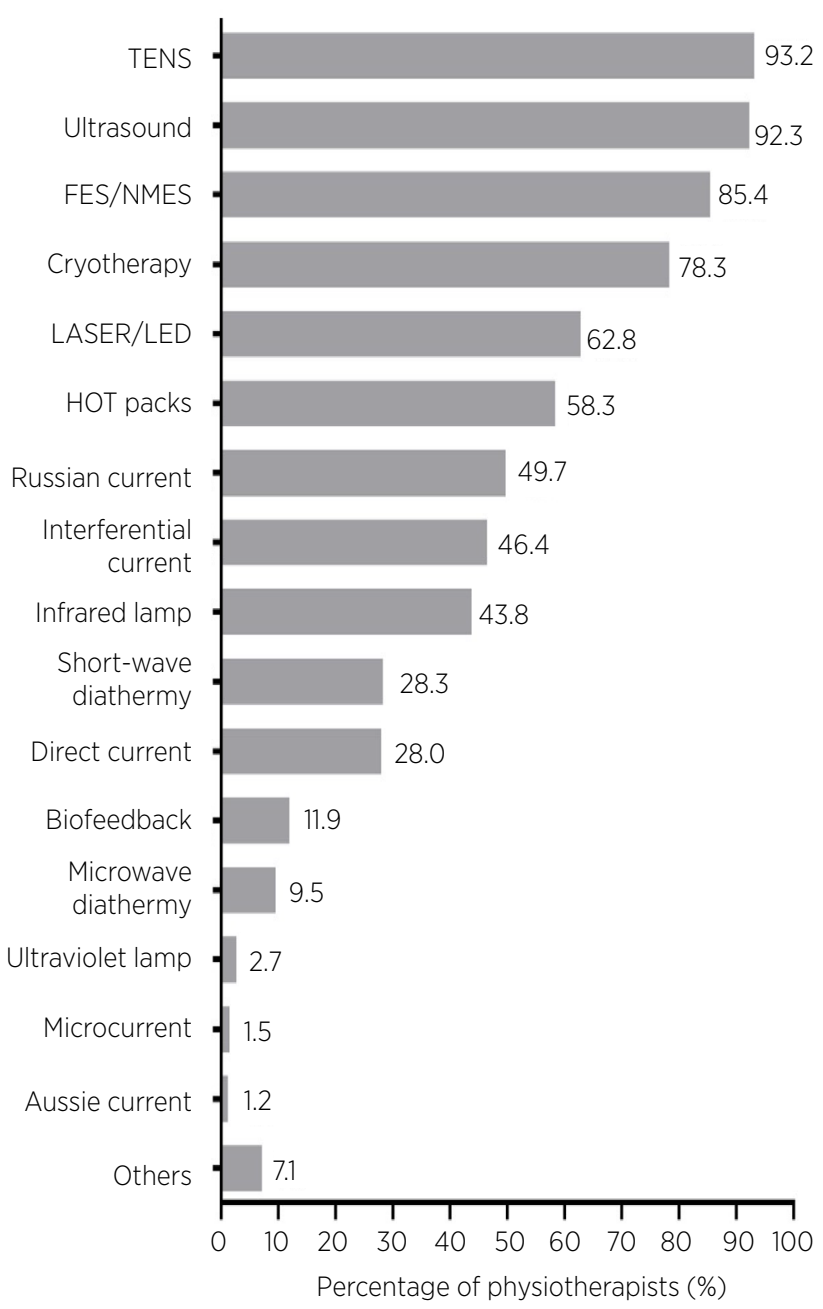

Figure 1. Availability of electrophysical agents at the physical therapists' workplaces 


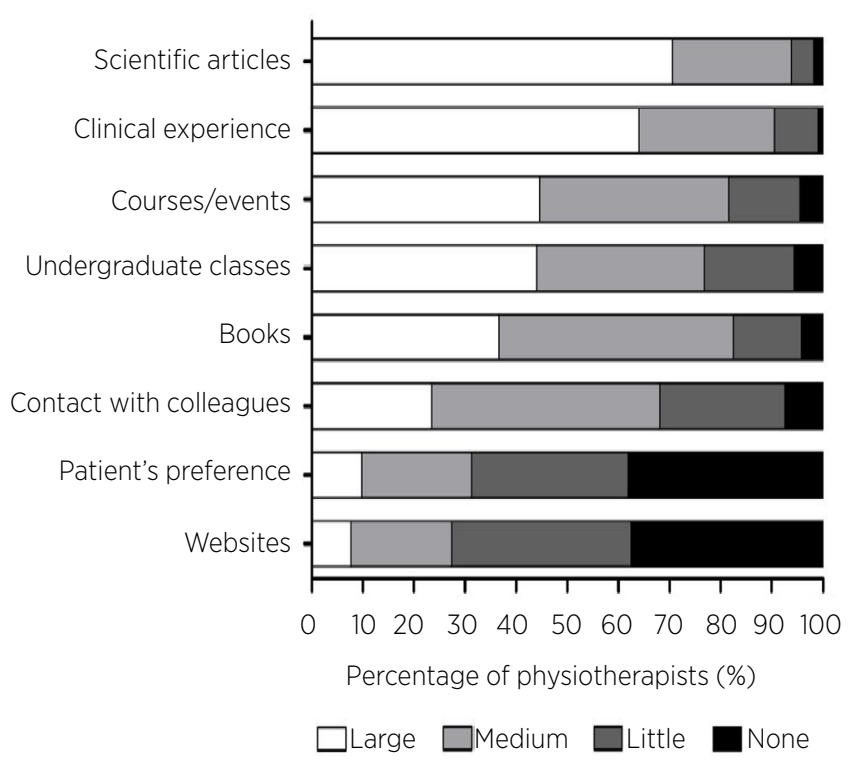

Figure 2. Influence of choice-factors for electrophysical agents by physical therapists

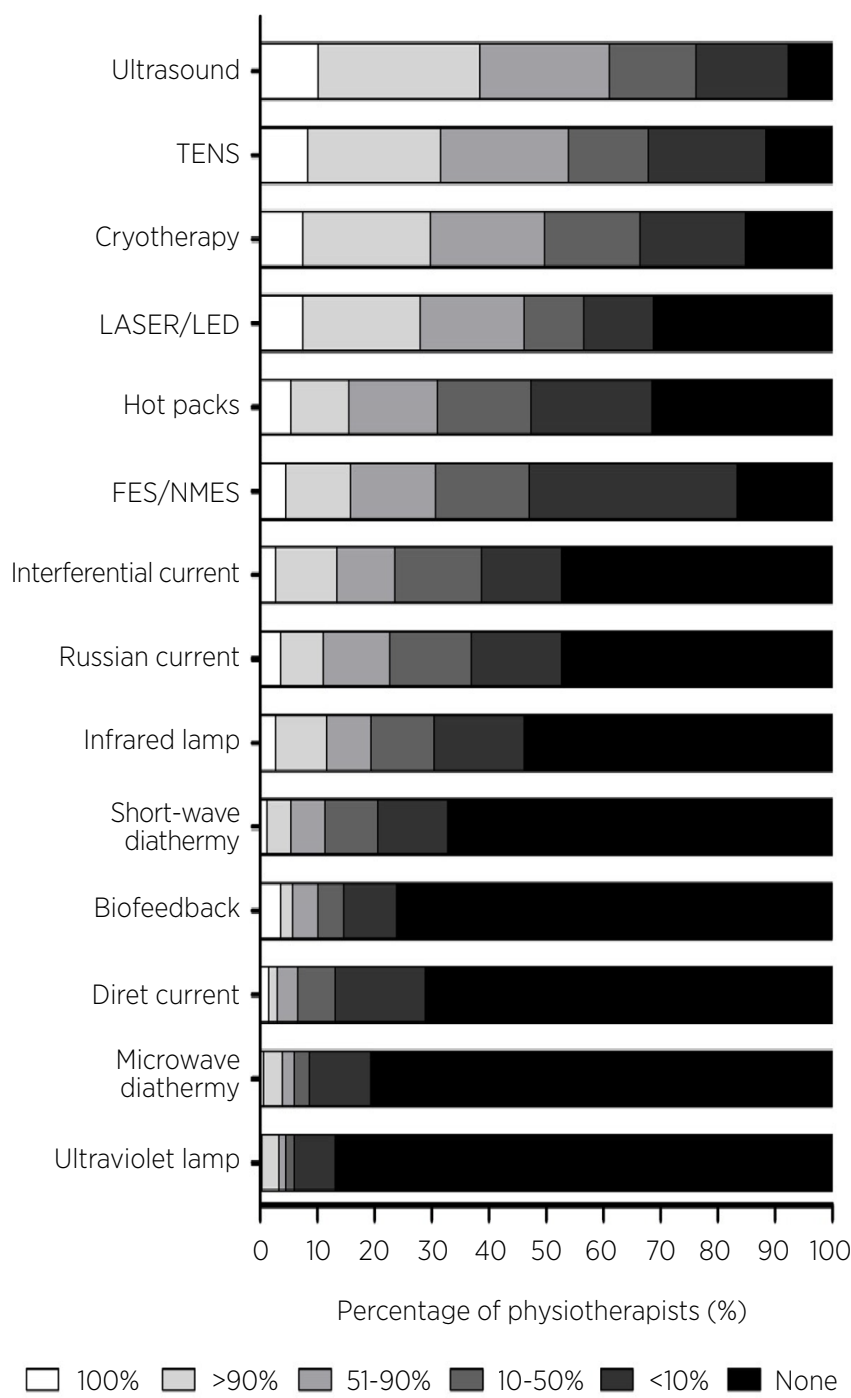

Figure 3. Percentage of patients treated with each electrophysical agent by physical therapists

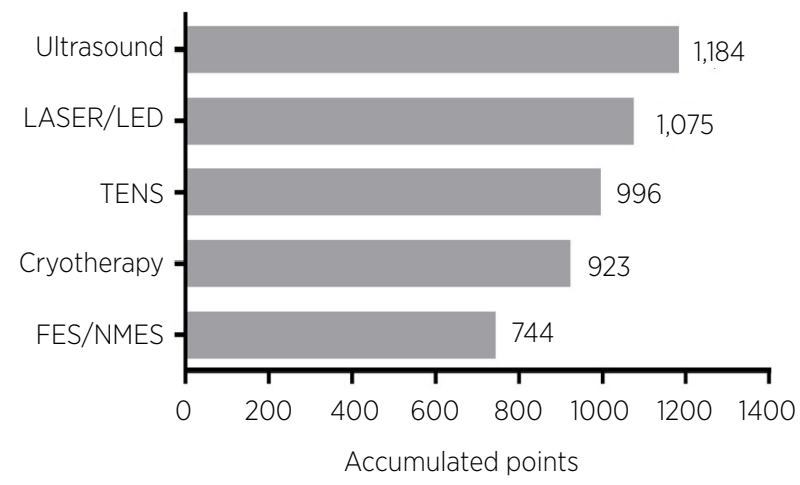

Figure 4. Top-five electrophysical agents elected by physical therapists as the most useful in clinical practice

\section{DISCUSSION}

To the best of our knowledge, this is the first study to describe the use profile of EPA by Brazilian physical therapists. Our main findings were: (1) EPA are widely used by orthopedic and sports physical therapists in Brazil; (2) ultrasound therapy, sensory (TENS) and excitomotor (FES/NMES) electrotherapy with pulsed currents, photobiomodulation (LASER / LED), cryotherapy, and hot packs are the most commonly available and used EPA; and (3) scientific articles and clinical experience are the most influential factors in choosing the EPA.

Physical therapy was recognized as profession in Brazil at 1969, and the scientific/technological progress regarding EPA has been important along these 50 years. Interestingly, approximately $45 \%$ of respondents in our study were younger than 30 years old, and almost $2 / 3$ hold their undergraduate degrees in the last decade. The young profile of most participants may be related to the preferences reported in this study. Note that our study assessed only professionals who declared work in orthopedic and/or sports physical therapy, unlike the studies published in the last decade that investigated physical therapists from mixed areas ${ }^{11,13,17,18}$. Moreover, physical therapy courses are not uniform worldwide. In Brazil, physical therapy is an undergraduate program carried out on a university basis of 4 to 5 years, whereas in some developed countries, physical therapists are trained in 2-3-year courses based on a technical program ${ }^{21}$. These distinct educational processes and other specificities of the profession in each country may influence the decision-making of physical therapists regarding the EPA.All aforementioned factors should be considered when interpreting our results and comparing them with previous studies in this field. 
Ultrasound, TENS, cryotherapy, and hot packs are the most frequently available EPA worldwide ${ }^{11,13,17,18}$, including Brazil (see Figure 1). As observed in our study, FES/NMES is also highly accessible to physical therapists in the $\mathrm{USA}^{13}$ and Israel ${ }^{17}$; at the same time, this EPA was found only in about $30-40 \%$ of physical therapy services in Australia ${ }^{11}$ and Japan ${ }^{18}$. However, the most noticeable difference between Brazilian physical therapists and professionals from other countries seems to be related to photobiomodulation. While LASER/LED devices were present in $63 \%$ of work environments in Brazil (see Figure 1), only $12-30 \%$ of physical therapists in other countries have access to this $\mathrm{EPA}^{11,13,17,18}$. The high availability of LASER/LED in Brazil does not seem to be related to costs, since photobiomodulation devices usually are more expensive than most EPA listed in our study. Also, this is not related to the type of equipment commercially available, since the Brazilian regulatory agency (Agência Nacional de Vigilância Sanitária - ANVISA) imposes similar restrictions as agencies from developed countries (e.g., Food and Drug Administration - FDA). Perhaps, the fact that Brazil is one of the world's greatest powers regarding scientific research output on LASER/LED applied to physical therapy is related to the popularity of this EPA among Brazilian physical therapists.

Evidence-based practice (EBP) has been increasingly recognized and used by physical therapists due to the increasing volume and accessibility of high-quality research ${ }^{21}$. The three pillars of EBP are the best scientific evidence, clinical expertise, and patient values ${ }^{22}$. A previous study found that $67 \%$ of the Brazilian interviewed physical therapists agreed that EBP is important for their clinical practice, and $90 \%$ of those professionals declared reading articles routinely ${ }^{21}$. This appreciation of the scientific evidence by Brazilian physical therapists is supported by our findings, which indicated to scientific articles as the main influence in the decision-making process on the usage of EPA (see Figure 2). Although clinical experience has been identified as the second most influential factor in the choice of EPA, the third pillar of EBP (i.e., patient values) was clearly devalued by Brazilian physical therapists. Similar results have been reported by Israeli physical therapists ${ }^{17}$, suggesting that in different countries patient's preference does not seems to be a key factor for the physical therapists' decision-making. These findings put in stake the actual level of knowledge about EBP by physical therapists.

The availability of EPA may be related to the frequency of use, but this association was not a common result in previous studies ${ }^{10,11,13,15,17}$. For instance, Robertson and Spurritt ${ }^{10}$ observed that short-wave diathermy was extremely common in the 1990s, but it was not frequently used by Australian physical therapists. On the other hand, Greco et al. ${ }^{13}$ found that only approximately $10 \%$ of respondents had access to photobiomodulation devices in their workplaces, but when accessible this EPA was used by approximately $82 \%$ of physical therapists. Moreover, few EPA may not be available in the workplace, but physical therapists may recommend its use at the patients' home, such as hot or cold packs ${ }^{11}$. However, in our study, the EPA most commonly available to physical therapists at their workplaces coincided with those most frequently used for treating patients: ultrasound, TENS, cryotherapy, LASER/LED, hot packs, and FES/NMES (see Figure 3). This use rate corroborates the EPA chosen by Brazilian physical therapists as the most useful in clinical practice: (1) ultrasound; (2) LASER/LED; (3) TENS; (4) cryotherapy; and (5) FES/NMES (see Figure 4). In other words, there is a congruence between the most commonly available EPA in the physical therapists' care settings, the EPA that professionals use commonly, and EPA to which they attribute higher value to treat their patients.

Ultrasound therapy, sensory electrotherapy (TENS), hot packs and cryotherapy are among the most commonly used EPA by physical therapists from different countries ${ }^{11,13,17,18}$. Ultrasound ${ }^{23}$ and TENS ${ }^{24}$ have proven to be beneficial for a few patients, but both therapies seems not to be effective for rehabilitation in a range of musculoskeletal disorders ${ }^{25-30}$. At the same time, the therapeutic value of superficial cooling and heating modalities remains unclear ${ }^{31}$, and there is even a trend against the use of icing in musculoskeletal rehabilitation ${ }^{32}$. Therefore, physical therapists' choice of the most used EPA in clinical practice is probably related to other factors, such as their personal experience. Findings from Greco et al. ${ }^{13}$, suggest that physical therapists who had access to EPA and with more than 10 years of experience were more likely to select "prior positive experience with the EPA" as a rationale for usage.

Interestingly, physical therapists from Australia ${ }^{11}$, Israel, ${ }^{17}$ and Japan ${ }^{18}$ have shown appreciation for the interferential current therapy, while this EPA is not used by almost half of the Brazilian physical therapists assessed in this study. There is also a reduced number of Brazilian physical therapists who use microwave and short-wave diathermy. These EPA were part of the routine of most English physical therapists assessed by Pope, Mockett and Wright ${ }^{15}$ during the 1990 's (around $84 \%$ and $97 \%$ of 
professionals, respectively). However, the lack of research on both microwave and short-wave diathermy seems to have been followed by the skepticism of clinicians, leading these EPA to a progressive decline within the physical therapy practice ${ }^{19}$. On the other hand, the use of photobiomodulation with LASER/LED in Brazil seems to be growing over the years, which is probably related to the favorable reports on treatment of several disorders, including tissue regeneration ${ }^{33}$, analgesic, ${ }^{34}$ and anti-inflammatory ${ }^{35}$ actions.

Studies regarding the application of EPA by physical therapists from different countries have had widely dispersed sample sizes, ranging between $46^{16}$ and 3,538 ${ }^{11}$ participants. The 376 participants in our study cannot be considered a faithful representation of the large population of Brazilian physical therapists, but our sample size is higher than most studies in this topic worldwide ${ }^{9,10,13-17}$. Furthermore, note that $84 \%$ of respondents worked in South and Southeast regions of Brazil. According to data from the regional councils, these two regions host almost 170,000 physical therapists (i.e., approximately $70 \%$ of Brazilian physical therapists); thus, a predominance of participants from South and Southeast of Brazil was expected. However, this irregular geographic distribution may be considered a confounding factor in our study, since we cannot exclude the possibility of specific regional characteristics in the use of EPA.

\section{CONCLUSION}

EPA are widely used by orthopedic and sports physical therapists in Brazil who responded to this survey. Therapeutic ultrasound, sensory and excitomotor electrotherapy with pulsed currents, photobiomodulation, cryotherapy, and hot packs are the most used EPA. Physical therapists affirm that their choice of EPA is mainly based on scientific articles and their clinical experience.

\section{REFERENCES}

1. World Confederation for Physical Therapy subgroups. International Society for Electrophysical Agents in Physical Therapy (ISEAPT) [Internet]. Milwaukee: Marquette University; 2017 [cited 2017 Oct 13]. Available from: http://www.wcpt.org/iseapt

2. Canadian Physiotherapy Association. Electrophysical Agents: contraindications and precautions: an evidence-based approach to clinical decision making in physical therapy. Physiother Can. 2010;62(5):1-80. doi: 10.3138/ptc.62.5
3. Cameron M. Physical agents in rehabilitation: from research to practice. Sant Louis: Elsevier; 2003.

4. Robertson VJ, Chipchase L, Laakso E, Whelan K, McKenna, L. Guidelines for the clinical use of electrophysical agents. Melbourne: Australian Physiotherapy Association; 2001.

5. Watson T. The role of electrotherapy in contemporary physiotherapy practice. Man Ther. 2000;5(3):132-41. doi: 10.1054/math.2000.0363

6. Chipchase L. Is there a future for electrophysical agents in musculoskeletal physiotherapy? Man Ther. 2012;17(4):265-6. doi: 10.1016/j.math.2012.04.001

7. Crosbie J, Gass E, Jull G, Morris M, Rivett D, Ruston S, et al. Sustainable undergraduate education and professional competency. Aust J Physiother. 2002;48(1):5-7. doi: 10.1016/ S0004-9514(14)60276-2

8. Laakso EL, Robertson VJ, Chipchase LS. The place of electrophysical agents in Australian and New Zealand entry-level curricula: is there evidence for their inclusion? Aust J Physiother. 2002;48(4):251-4. doi: 10.1016/S0004-9514(14)60164-1

9. Lindsay D, Dearness J, Richardson C, Chapman A, Cuskelly G. A survey of electromodality usage in private physiotherapy practices. Aust J Physiother. 1990;36(4):249-6. doi: 10.1016/ S0004-9514(14)60527-4

10. Robertson VJ, Spurritt D. Electrophysical agents: implications of their availability and use in undergraduate clinical placements. Physiotherapy. 1998;84(7):335-44. doi: 10.1016/ S0031-9406(05)63462-1

11. Chipchase L, Williams MT, Robertson V. A national study of the availability and use of electrophysical agents by Australian physiotherapists. Physiother Theor Pract. 2009;25(4):279-6. doi: 10.1080/09593980902782611

12. Taylor E, Humphry R. Survey of physical agent modality use. Am J Occup Ther. 1991;45(10):924-31. doi: 10.5014/ajot.45.10.924

13. Greco J, Lamberg EM, McKenna RF, Muratori LM. Trends in availability and usage of biophysical agents among physical therapists in the United States. Phys Ther Rev. 2018;23:(2);116-23. doi: 10.1080/10833196.2018.1449921

14. Lindsay D, Dearness J, McGinley C. Electrotherapy usage trends in private physiotherapy practice in Alberta. Physiother Can. 1995;47(1):30-4.

15. Pope GD, Mockett SP, Wright JP. A survey of electrotherapeutic modalities: ownership and use in the NHS in England. Physiotherapy. 1995;81(2):82-91. doi: 10.1016/S0031-9406(05)67050-2

16. Cooney M, Gallen C, Mullins G. A survey of ownership and use of electrotherapeutic modalities in public outpatient departments and private practice in the Republic of Ireland. Physiother Irel. 2000;21:3-8.

17. Springer S, Laufer $Y$, Elboim-Gabyzon M. Clinical decision making for using electro-physical agents by physiotherapists, an Israeli survey. Isr J Health Policy Res. 2015;4:14-9. doi: 10.1186/s13584-015-0015-x

18. Abe Y, Goh A, Kei Miyoshi K. Availability, usage, and factors affecting usage of electrophysical agents by physical therapists: a regional cross-sectional survey. J Phys Ther Sci. 2016;28(11):3088-94. doi: 10.1589/jpts.28.3088 
19. Shah SGS, Farrow A. Trends in the availability and usage of electrophysical agents in physiotherapy practices from 1990 to 2010: a review. Phys Ther Rev. 2012;17(4):207-26. doi: 10.1179/1743288X12Y.0000000007

20. CoFFiTO-Conselho Federal de Fisioterapia e Terapia Ocupacional. Perguntas mais frequentes: quantitativo de profissionais [Internet]. Brasília, DF: Coffito, 2018 [cited 2019 Jan 20]. Available from: http://www.coffito.gov.br

21. Silva TM, Costa LC, Garcia AN, Costa LO. What do physical therapists think about evidence-based practice? A systematic review. Man Ther. 2015;20(3):388-401. doi: 10.1016/j.math.2014.10.009

22. Herbert R, Jamtvedt G, Hagen KB, Mead J. Practical evidencebased physiotherapy. 2nd ed. Oxford: Elsevier, 2011.

23. Wu Y, Zhu S, Lv Z, Kan S, Wu Q, Song W, et al. Effects of therapeutic ultrasound for knee osteoarthritis: a systematic review and meta-analysis. Clin Rehabil. 2019;33(12):1863-75. doi: 10.1177/0269215519866494

24. Zhu Y, Feng Y, Peng L. Effect of transcutaneous electrical nerve stimulation for pain control after total knee arthroplasty: a systematic review and meta-analysis. J Rehabil Med. 2017;49(9):700-4. doi: 10.2340/16501977-2273

25. Griffin XL, Parsons N, Costa ML, Metcalfe D. Ultrasound and shockwave therapy for acute fractures in adults. Cochrane Database Syst Rev. 2014;23;(6):CD008579. doi: 10.1002/14651858.CD008579.pub3

26. Ebadi S, Henschke N, Nakhostin Ansari N, Fallah E, van Tulder MW. Therapeutic ultrasound for chronic low-back pain. Cochrane Database Syst Rev. 2014;(3):CD009169. doi: 10.1002/14651858.CD009169.pub2

27. Brosseau L, Casimiro L, Welch V, Milne S, Shea B, Judd M, et al. WITHDRAWN: Therapeutic ultrasound for treating patellofemoral pain syndrome. Cochrane Database Syst Rev. 2013;(2):CD003375. doi: 10.1002/14651858.CD003375.pub2
28. Gibson W, Wand BM, O'Connell NE. Transcutaneous electrical nerve stimulation (TENS) for neuropathic pain in adults. Cochrane Database Syst Rev. 2017;(9):CD011976. doi: 10.1002/14651858.CD011976.pub2

29. Khadilkar A, Odebiyi DO, Brosseau L, Wells GA. Transcutaneous electrical nerve stimulation (TENS) versus placebo for chronic low-back pain. Cochrane Database Syst Rev. 2008;(4):CD003008. doi: 10.1002/14651858.CD003008.pub3

30. Gibson W, Wand BM, Meads C, Catley MJ, O'Connell NE. Transcutaneous electrical nerve stimulation (TENS) for chronic pain - an overview of Cochrane Reviews. Cochrane Database Syst Rev. 2019;2019(4):CD011890. doi: 10.1002/14651858.CD011890.pub3

31. French SD, Cameron M, Walker BF, Reggars JW, Esterman AJ. Superficial heat or cold for low back pain. Cochrane Database Syst Rev. 2006;(1):CD004750. doi: 10.1002/14651858.CD004750.pub2

32. Dubois B, Esculier JF. Soft-tissue injuries simply need PEACE and LOVE. Br J Sports Med. 2019;54(2):72-3. doi: 10.1136/ bjsports-2019-101253

33. Alves AN, Fernandes KP, Deana AM, Bussadori SK, MesquitaFerrari RA. Effects of low-level laser therapy on skeletal muscle repair: a systematic review. Am J Phys Med Rehabil. 2014;93(12):1073-85. doi: 10.1097/PHM.0000000000000158

34. Chow RT, Johnson MI, Lopes-Martins RA, Bjordal JM. Efficacy of low-level laser therapy in the management of neck pain: a systematic review and meta-analysis of randomised placebo or active-treatment controlled trials. Lancet. 2009;374(9705):1897908. doi: 10.1016/S0140-6736(09)61522-1

35. Yamaura M, Yao M, Yaroslavsky I, Cohen R, Smotrich M, Kochevar IE. Low level light effects on inflammatory cytokine production by rheumatoid arthritis synoviocytes. Lasers Surg Med. 2009;41(4):282-90. doi: 10.1002/Ism.20766 